\title{
COLLABORATIVE COMMUNICATIVE TECHNIQUES IN TEACHING FOREIGN LANGUAGES
}

\author{
Lucia-Larissa PALEA, Gabriela MIHĂILĂ-LICĂ \\ "Nicolae Bălcescu" Land Forces Academy, Sibiu, Romania \\ luciapalea@yahoo.com, mihailag2001@yahoo.com
}

\begin{abstract}
Collaborative communicative techniques are essential in teaching foreign languages. Our article presents a few modern methods and techniques used in the practice of teaching foreign languages. The aim was to discover what methods are still the most frequently used in the teaching of foreign languages, focusing on communicative techniques in teaching German as a foreign language. The use of collaborative communicative techniques during foreign language classes enables the students to easily acquire vocabulary by means of a process that is both stimulating and enjoyable. The students develop what the specialists call "learner autonomy", becoming more confident and independent. The conclusion we have reached is that traditional methods still coexist with modern ones, an eclectic approach being highly efficient in teaching foreign languages.
\end{abstract}

\section{Keywords: communication, techniques, vocabulary, language interaction, German}

\section{Introduction}

Learning foreign languages has always been viewed as useful and important. Wer fremde Sprachen nicht kennt, weiß nichts von seiner eigenen [1] (He who doesn't speak foreign languages knows nothing about his own mother tongue) says Johann Wolfgang von Goethe emphasizing the usefulness of being multilingual.

\section{Developing a learner's communicative competence by means of collaborative techniques}

In the 1970s - almost ten years after the period when numerous changes made themselves felt in the field of English language teaching - it became obvious for German teachers that the structural approach of the audio-lingual method was unable to cover the requirements of those times because of its endless repetitions and drills. The teachers understood that learning
German as a foreign language was not just a matter of memorizing words and structures, but a complex educational experience. In order to function well in a modern society, a person needs to be a competent communicator. The communicative approach is not just a highly structured method, but rather a large set of ideas, generally accepted by the foreign language teachers as a good teaching practice.

The main aim of teaching a foreign language is to develop the learners' communicative competence.

Communication in a foreign language is based on much more than the learners' linguistic competence, because fluent speakers interact linguistically due to their ability to interact spontaneously and cope with a large variety of everyday situations.

Developing language skills is very important, even more important than teaching content. The students must be 
equipped with tools for language performance in the real world. On the one hand, the students must learn to use the foreign language functionally, to achieve real-life goals, the way people do in real life situations. On the other hand, students must acquire confidence in their linguistic abilities and become less frightened of making mistakes. As long as the speaker gets his/her message through, the teacher should not correct the mistakes he/she makes. Furthermore, the students must learn the foreign language by using it, by communicating and thus they learn both grammar and vocabulary in a meaningful context.

The term "communicative competence" was firstly used by the sociolinguist Dell H. Hymes [2]. After having studied Chomsky's concepts of competence and performance, he came to the conclusion that linguistic competence is only one aspect of the competent speakers' communicative competence, for example their overall ability to interact by means of the language. Analyzing the native speaker's communicative behaviour, linguists concluded that the proficient speaker's capacity to communicate is dependent on practical factors, on elements belonging to his general knowledge and on the unwritten rules that guide human communication and society. Knowing the world and the society in which every linguistic interaction takes place enables competent speakers to express more significance than is carried by the meanings of the words they make use of. Furthermore, the competent communicator also knows how to utilise language for a variety of purposes, in order to obtain the desired results and to avoid damaging consequences.

In order to better understand the significance of communicative competence, we also have to analyze the nature of communication and identify some of its basic characteristics. Communication is based on meaning as it aims to convey meaning through various channels, such as language or paralanguage. It is also interactional: it requires at least two participants who interact. Communication is structured, consisting of an endless range of types of discourse, such as the discourse of advertising, the journalistic discourse, the discourse of the court of justice, of telephone conversations, of letter writing or of classroom interactions. Moreover, another characteristic of communication is that of being appropriate, the interlocutors having to adapt their discourse both to the social status of the speaker and the listener, their roles in the communicative exchange and the discourse type, such as informal and formal correspondence, forms, telephone conversations, etc., each of them requiring certain conversational formulas and a specific type of vocabulary.

\section{Communicative teaching}

There are certain things on which almost all foreign language teachers agree nowadays. G. Murdoch accurately summed up the essence of the current philosophy in this domain: "It is felt that the teacher's job is not so much to offer descriptions of language or models to be learnt, but rather to create conditions in the classroom that will enable students to learn by becoming engaged in activities or working on tasks. [...] The teacher is no longer expected to dominate all work in the classroom - he sets up conditions and activities that will make it possible for students to operate with language because they have a real interest in the outcome of the tasks. The teacher's success is therefore closely linked to his ability to stimulate interest in a subject." [3]

Those that have adopted the communicative method started from the fact that communication and language depend on each other. Different from the structural approach of the previous generation of pedagogues, the communicative method of teaching foreign languages emphasizes the functional potential of evidencing the role of language as an indispensable instrument for 
common interaction. In contrast to the previous generations' insistence on structure and form, teachers who use communicative methods focus on meaning and interaction, especially on oral communication. Communicative teachers realized that they could no longer ignore the socio-cultural context of interactions, or the students' psychological world. Moreover, in order for the activity to be successful, the learners must be motivated to communicate. They have to be actively involved in the task, eager to express their thoughts and feelings. The teacher must arouse their interest by choosing motivating materials and interesting exercises, as well as by selecting attractive audio and visual materials. "The audio-visual documents can be very short, from several seconds to a couple of minutes: one or two scenes of a film, extracts from TV news bulletins, weather reports, interviews". [4]

When taking into consideration the teaching focused on communication, we notice that both the teacher's and the student's roles are different from the roles they held in the case of the traditional methods. In the past, the teacher was seen as a source of information and as an unchallenged leader, while learners were looked upon as passive recipients, whose main objective was to memorize the information provided. The communicative class is student-centered, the teacher and the learners being partners in a cooperative venture.

Due to the fact that learning a foreign language can not be done in isolation and that the main purpose of this effort is communication with others, we are of the opinion that the collaborative techniques need to be employed extensively during the classes. These help teachers in offering the students more speaking time since students enjoy working with their colleagues which increases their motivation increases. Speaking about the benefits of collaborative learning, Dr. Claude Romney affirms that "On a personal level, students are pleased to be able to share their difficulties with others. They gain confidence from observing that if their team-mates can solve problems, they will also be able to overcome them. Speaking in front of a small group with which they are familiar, rather than in front of the whole class, is also less stressful. In addition, participants are better able to accept criticism, since they themselves are also allowed to criticize. On a social level, the students' level of tolerance and acceptance of other people's viewpoints is increased, a skill which no doubt is beneficial in real-life situations where one also often has to be prepared to compromise. They also form close friendships with their team-mates, and many stress that for that reason they look forward to coming to class. Last but not least, on an academic level, there are definite gains in conformity with Johnson and Johnson's findings that "cooperative learning experiences promote higher achievement than do competitive and individualistic experiences" (1985, p. 104). [5] Nowadays, collaborative communicative techniques are frequently used in foreign language teaching. Collaborative learning is a teaching and learning technique in which learners work together to explore a significant question or to create a project. With collaborative communicative language teaching, students are encouraged to think and be creative.

\section{Communicative techniques in teaching German as a foreign language}

There are lots of communicative techniques in teaching foreign languages, the most frequently used being role-plays, communication activities or games. In Romania, German is taught in schools both as a mother tongue and as a foreign language. German courses are organized at the German Cultural Centers, where the teachers' aim is the shaping of the students' communicative competence and the development of basic communicative skills. Communicative teachers reject the idea of 
excessive memorization and repetition as techniques for learning German. Instead, they consider that language learning is a two-way process: using the language in order to learn it and learning the language in order to use it. Therefore, the learners have to assimilate the foreign language by trying to communicate. Fortunately, in Romania there still is the German speaking community, especially in Transylvania, so German speakers are also frequently encountered outside the German classes. Learning is a natural process which takes place inside the learner by the emotional and physical involvement of the person in the activity. So, language learning is much more efficient if the learners are actively participating in the process, and if they are emotionally involved in the process of language learning.

A new technique in teaching German as a foreign language is the contextbased approach. Nikola Ferling's [6] opinion is that learning new words in context and not isolated from it is a very effective strategy in German language learning. One word used in different contexts may have quite different meanings. Thus, by simply learning the definitions of the word without any examples of when and where that word occurs will not help the German learners to fully understand its meaning. Learning words without any reference to the whole context is just a memory exercise and it makes it very difficult for the learners of German or of any other language to use those words in oral and written communication. Focusing on the context in which the word appears is actually a very good way of acquiring vocabulary. German learners who have very well developed reading skills also take advantage of their background knowledge both in creating expectations about the kind of the vocabulary that will be encountered in the reading part and in the way of understanding the context.

Furthermore, one of the typical characteristics of the German language is the presence of the multitude of compound words. "Some German words are so long that they have a perspective", considered Mark Twain [7]. Even if one does not know exactly what the meaning of a compound word is, he/she can guess it by translating the parts of the compound. For example, words like weltbekannt which means known all over the world, world-famous (Welt $=$ world + bekannt $=$ famous), Naturschutzgebiet (Natur $=$ nature + Schutz $=$ protection + Gebiet $=$ area $)$, Lastkraftwagenfahrer (Lastkraftwagen = truck + Fahrer $=$ driver or Fußballweltmeisterschaftqualifikationsspiel (World cup qualifying match) can be divided into their compound parts and translated. German teachers must also teach their students that a compound word always has to be translated in Romanian from right to left, the last word always being the basic word, and this one also establishes the gender of the compound noun, e.g. die Kinder + das Buch $=$ das Kinderbuch (book for children).

Taking all the ideas expressed above into consideration, we can affirm that the use of collaborative communicative techniques during German language classes enables the students to easily acquire vocabulary by means of a process that is both stimulating and enjoyable. The students develop what the specialists call "learner autonomy", becoming more confident and independent.

When it comes to the roles that the teachers have to play when employing collaborative communicative techniques, these are very well summarized by Georgeta Obilişteanu and Brânduşa-Oana Niculescu in Teacher Control in the Second Language Classes:

"The modern methodology is learnercentred, allowing students to take centre stage and get a hands-on practical experience of using the language for communicative purposes. Nevertheless, this distinction should not lead to the diminishing of the teacher's power and authority since making the shift from the 
teacher as total controller of all that happens in the class to mediator/facilitator supposes a multitude of roles that he/she has to assume within the classroom. The efficiency of a foreign language teacher can be determined by the level of development of the language competences as mirrored in the learners' listening, reading, writing and speaking skills. The necessity and importance of classroom teaching control must be emphasized, as well as the roles a teacher plays in achieving the objectives proposed for each lesson." [8]

\section{Conclusion}

The above analysis leads to the conclusion that the communicative competence has a much wider aim than the mere linguistic competence. In other words, communicative competence is synonymous with the ability to use the language accurately as far as grammar and vocabulary are concerned, appropriately, suitable to the social, situational context in which the exchange takes place, functionally, so as to use the language tactfully and politely, and last but not least competently in terms of cultural background.

In conclusion, we must clearly underline the idea that communicative techniques are frequently used by foreign language teachers, but in practice there often appears a mixture of foreign language teaching methods. Teaching German as a foreign language by using collaborative communicative techniques helps the students build up confidence in their communicative abilities. To sum up, learning German by means of the above mentioned techniques is an effective strategy in learning German as a foreign language.

\section{References}

[1] Goethe, Johann Wolfgang, Werke - Maximen und Reflexionen. Hamburger Ausgabe, vol. München, dtv, 1981, p. 508.

[2] D. H. Hymes, Dell H., "On Communicative Competence“, Sociolinguistics. Selected Reading, edited by J. B. Pride und J. Holmes, Harmondsworth: Penguin Education, 1972, pp. 269-293.

[3] Murdoch G., Practising what we preach - A trainee-centered approach to in-service training, in English Teaching Forum, 28, 4, 1990.

[4] Obilișteanu, Georgeta, "Developing Students' Speaking and Writing Activities in the Foreign Language Class",in Revista Academiei Forţelor Terestre, anul XII, nr. 3 (47), Editura Academiei Forțelor Terestre, Sibiu, pp. 168-172, 2007.

[5] http://www.ucalgary.ca/newcurrents/Vol3.6/Benefits.html 19.04.2016.

[6] Ferling, Nikola, Lesen im DaZ - Unterricht, in: Kaufmann, Susan, Zehnder, Erich, Vanderheiden, Elisabeth, Frank, Winfried, Fortbildung für Kursleitende Deutsch als Fremdsprache. Band 2. Didaktik. Methodik. Ismaning, Hueber, 2008, p. 41.

[7] Twain, Mark, A Tramp Abroad, Oxford: Oxford University Press, 1880, p. 287.

[8] Obilişteanu Georgeta, Niculescu Brânduşa-Oana, Teacher Control in the Second Language Classes, Proceedings II of the 21st International Scientific Conference KBO, , pp. 338-343, Sibiu, Romania, 11-13 June, 2015. 